\title{
LANDSLIDE IN NACHTERSTEDT OF GERMANY
}

\author{
Moraiti E. ${ }^{1}$, Christaras B. ${ }^{2}$ and Brauer R. ${ }^{3}$ \\ ${ }^{1}$ IGME, Athens, GR, e-mail:moraiti@igme.gr \\ ${ }^{2}$ Aristotle University of Thessaloniki School of Geology, Lab. of Engineering Geology \& Hydrogeology, \\ Lab,GR,e-mail: christar@geo.auth.gr \\ ${ }^{3}$ Saxon State Office for the Environment, Agriculture and Geology,e-mail:Rainer.Brauer@smul.sachsen.de
}

\begin{abstract}
On July 18, 2009, an important landslide occurred in Nachterstedt City toward to the artificial Concordia Lake, which was created, in 1994, at the place of an old coal mine, at the edge of the city. The area is located to North-East of Harz, between the cities of Aschersleben and Quedlingburg. An underground coal mine is responsible for this damage which caused the damage of a privet house and a big building. Three people were also died. The mine apparently closed in 1991 whereupon it was converted into a recreation area. The landslide was caused by the increase of the groundwater level, in the coal mine, after a heavy rain, in relation to the water level of the lake.
\end{abstract}

Key words: Nachterstedt, landslides, halocinetic movements.

\section{Introduction}

On July, 18, 2009, an important landslide created at coastal part of Nachterstdt City toward to Concordia Lake. Three people were died and a privet two-floor house was destroyed together with a big building (Fig.1). The sliding was related to existence of a coal mine under the city. On Feb. 2, 1959, a similar landslide, of 5.8 million $\mathrm{m}^{3}$, had also activated by the coal mine works. One min worker died and many reactions were activated, in the East Germany of that period, regarding to the coal mine exploitation method used.

Nachtersted was offered, in 961, to Baron Gero. Many historians refer that people leave in this city, from $500 \mathrm{AD}$. The coal started to be exploited, in $19^{\text {th }} \mathrm{c}$. AD. The first boreholes were performed in 1842/43 and in 1957, the Concordia coal mine, a field of 600 hectares, started to be exploited. It is the area of the present lake, which was responsible for the occurred landsides. The exploitation of the $30 \mathrm{~m}$ thick coal layer was started at a depth of $15 \mathrm{~m}$. tunnel).

\section{Geologic Overview}

During the Eocene in the area of the Ascherslebener saddle tectonic movements caused an uprise of the deep lying Zechsteinsaltlayers. The salt moved away from the rims of the saddle into its core. Hereby sinks were created into which from NW marine Sediments could transgress. During phases of reduced sink movements moors or swamps developed from which the exploited brown coal has been mined. The general geological structure of the Paleogene at 

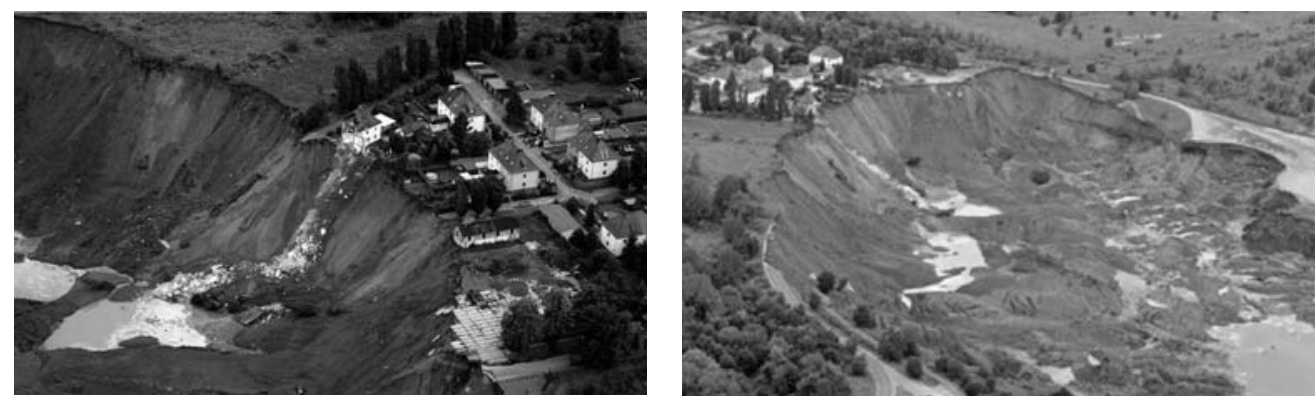

Fig. 1: The landslide of July 19, 2009, in Nachterstedt (Petley, 2009, http://daveslandslideblog.blogspot.com/).

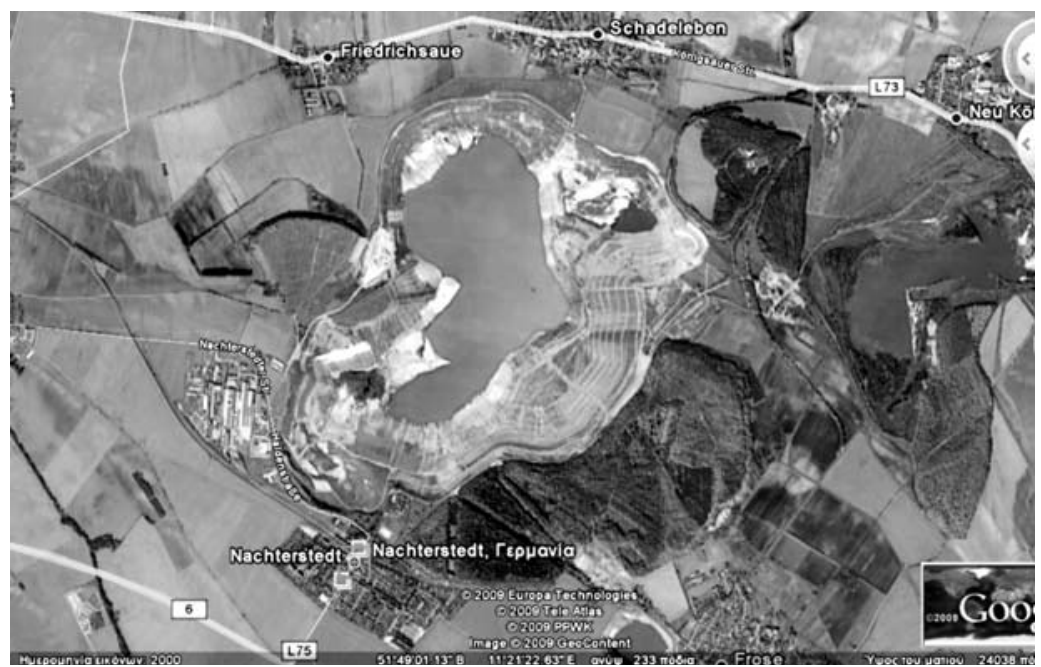

Fig. 2: Location of Nachterstedt City (http://earth.google.com/download-earth.html/.

Nachterstedt is characterized by rhythmic and cyclic sedimentary sequences (Balaske, 1992, 1998). These cycles begin with sands, partly transgressive conglomerates, followed by silty sand and silt. The final members of such cycles form the coal seams. Reasons for the cyclic structure were interactions between global-eustatic and more local modifying factors (Salt tectonics halocinetic movements). In particular, during the middle Eocene in the descending part of the basin area of Nachterstedt three workable coal beds could develop. The age of these autochthonous coals, supported by tree stumps and root horizons, is clearly determined on the fossil content of the intermediate marine sediments and on pollen dating. By invasion of humic acids previously existing micro-and macro-fossils (foraminifera, bivalves and gastropods) had been dissolved. For stratigraphic classifications therefore mainly siliceous dinoflagellates have been used. These species characterise mainly a coastal habitat. Shallow marine sedimentary structures as well as local sand dunes in the profile series support such an interpretation (Woldstedt, 1926, Voigt, 1963, Ahrendt et al., 1995).

The section of Nachterstedt (Balaske, 1998) begins with about $35 \mathrm{~m}$ of a so called basic clay in which Intercalations of silts and sand might occur. This lowermost sequence is followed by 15$20 \mathrm{~m}$ of sand- and siltbeds locally with browncoalseams. The completion of this cycle is seam 


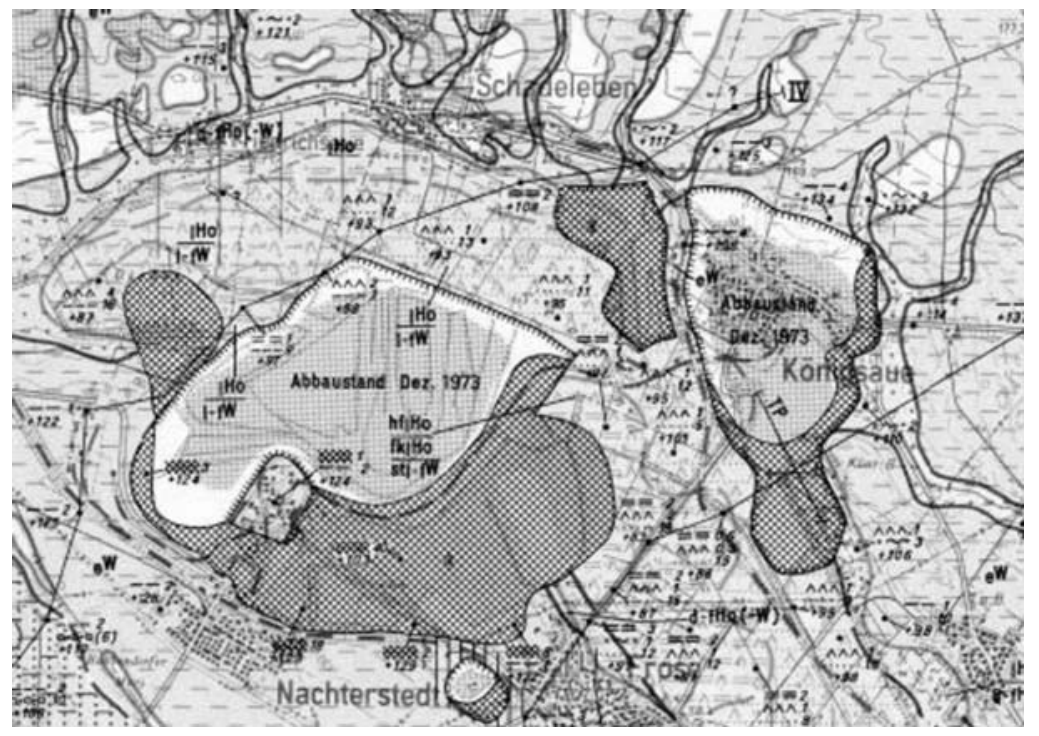

Fig. 3: Geological map 1:50.000 of Nachtersted area, sheet 2363 Quedlinburg, horizon card IE Ho, editorship conclusion January 1975 (Karpe,1975, 1986a, 1986b).

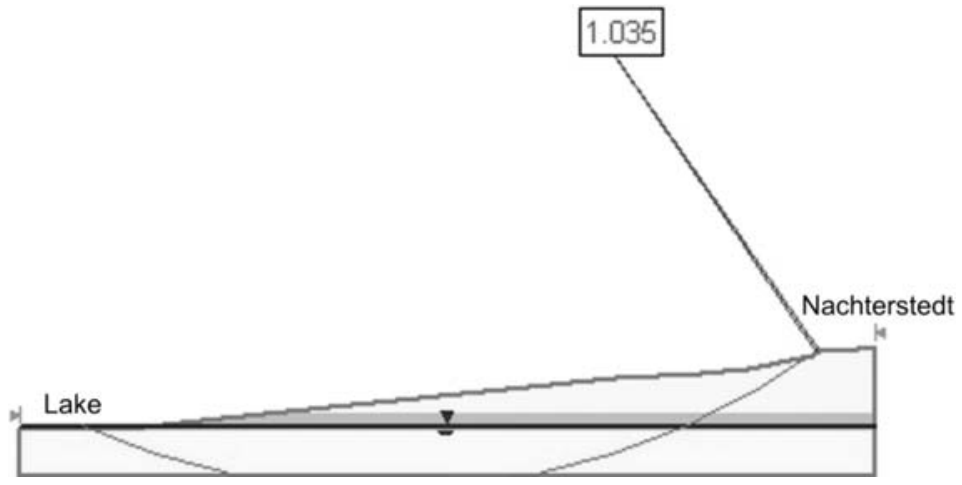

Fig. 4: The damaged area together with a schematic slope stability analysis, showing the limited stability conditions of the area in rain conditions.

Nr. I, also called Lower seem. On top follow about 30m of silts and sands with two further coal horizons, the so called seem II and seem III, respectively middle and upper seem. . The final part of the middle Eocene is characterised by several meters thick, transgressive coarse sand. The so called Latdorf-Formation of the Upper Eocene then starts with few meters of glauconitic fine sands (Lehmann, 1933, Knochenhauer, 1950, Waltemate, 1956, Seichter, 1958).

The entire sequence of Nachterstedt was marked by climate changes and fluctuations in sea level and modified by the local halocinetic development of underlying salt structures. In particular, the halocinetic lowering of the marginal basins had an influence on the geometry of the coalbeds: While the areas far from the Ascherslebener saddle had already been flooded, the areas more near to the central saddle structure came into lofty positions and so into the influ- 
ence of groundwater. This allowed an ongoing growth of the different swamps during the embankment of marine sediments in the areas of the adjacent coasts and seas.

\section{The landside}

The area, in study, covers the Northern coastal part of Nachtersted City, in the eastern part of Germany, located to North-East of Harz, between the cities of Aschersleben and Quedlingburg. An artificial lake was created, in 1994, at the open pit of a coal mine, which stopped to be exploited in 1991. In the geological map, 1:25000, of 1926, the displacement of the railway line, to the south, out of the coal outcrop, is referred (Petley, 2009). The southern coast of this lake is unstable because of the change of the water level, during the time (Eberhardt, 1969, Karpe, 1986a, 1986b, Blumenstengel \& Unger, 1993, Blumenstengel \& Volland, 1995, Blumenstengel et al., 1996).

According to the geological map, 1:50.000 of Fig. 3, the area, where the sliding occurred, above the coal layer, consists, of a) $1 \mathrm{~m}$ man made deposits, b) $2 \mathrm{~m}, \mathrm{gW}$ : löss, c) $11 \mathrm{~m}$, $\mathrm{fI}$ medium to coarse grained sand, d) $3 \mathrm{~m},{ }_{\mathrm{g}} \mathrm{H}$ : gravel and sand, e) $6 \mathrm{~m},{ }_{\mathrm{gf}} \mathrm{EV}$ : medium to coarse grained sand, f) $2 \mathrm{~m},{ }_{\mathrm{gf}} \mathrm{EV}$ sand g) $4 \mathrm{~m},{ }_{\mathrm{gf}} \mathrm{EV}$ : medium to coarse grained sand, f) $3 \mathrm{~m},{ }_{\mathrm{gf}} \mathrm{EV}$ : fine to medium sand.

The landside refers to a subsidence of approximately one million cubic meters ( 1.31 million cy) of soil. There were no reports of cracking or settlement of soils in the vicinity prior to the failure. Nevertheless, a quick slope stability calculation, for rain conditions, showed a limited safety factor which easily could explain the occurrence of that sliding, which wasn't the first during the last 50 years. The landslide wasn't, probably, due to the presence of the old mine, itself, but its presence probably contributed to the activation of the sliding. The sliding caused a massive wake on the Concordia Lake, which flooded the surrounding shores and flushed boats onto the banks. As it was mentioned previously, the lake is a result of brown coal surface mining operations and was generated in 1991. Currently, Concordia Lake covers approximately 350 Hectares (865 acres) and is up to 30 meters (100 ft) deep.

According to the analysis of Fig. 4, the slope had a limited stability, of SF=1.035, which negatively changed after a very strong rainfall. The damage was very important and for this reason a further investigation is needed, for determining the stability frame, which doesn't only depends on the rain but also on the existence of underground openings which remained after coal exploitation and influence on the stability of the coastal zone of the living area of the village.

\section{Conclusion}

The living area of Nachterstedt is located over a coal mine, which is not active any more but important underground opening decrease the stability of the ground at the surface.

The stability analysis gave a safety factor 1 , which very easily can be changed, under specific weather conditions. The recent landslide is the result of this limited stability conditions of the area.

The last landslide showed that a completed ground stability investigation is necessary to be performed, at the coastal zone, for avoiding any further sliding, in the future.

\section{References}

Ahrendt, H., Köthe, A., Lietzow, A., Martheine, D. \& Ritzkowski, S. (1995): Lithostratigraphie, Biostratigraphie und radiometrische Datierung des Unter-Eozäns von Helmstedt (SE-Nieder- 
sachsen). Z. dt. geol. Ges., 146 (H2): S. 450-457; Hannover

Balaske, P. (1992): Nachweis mariner und marin beeinflußter Sedimente in den Zwischenmittel der eozänen Braunkohlen bei Aschersleben in der östlichen subherzynen Senke.Zbl. Geol. Paläont., Teil I, 12: 2953-2962; Stuttgart

Balaske, P. 1998. Die marin beeinflußten Sande im Tertiär von Nachterstedt-Schadeleben inder östlichen Subherzynen Senke - Sedimentologie, Fazies und stratigraphische Bewertung; 58p. (unpublished. Dis., Durham Univ)

Blumenstengel, H. \& Unger, K.-P. (1993): Zur Stratigraphie des flözführenden Tertiärs der Egelner Mulden.(Sachsen-Anhalt) Geol. Jb., A 142.: 113-129; Hannover

Blumenstengel, H. \& Volland, L. (1995): Geologische Abschlußdokumentation stillgelegter Braunkohlentagebaue am Beispiel des Referenzprofils im Tagebau Merseburg-Ost. Mitt. Geol. LA Sachsen- Anhalt, 1: 55-67; Halle

Blumenstengel, H., Krutzsch, W., Volland, L. (1996): Revidierte Stratigraphie tertiärer Ablagerungen im südlichen Sachsen-Anhalt, Teil 1: Raum Halle-Merseburg. Hall. Jb. f. Geowiss., Reihe B, Beih. 1:

Eberhardt, F. (1969): Geologischer Bau und Erdgasführung des Subherzynen Beckens. $\square$ unveröff. Diss. BA Freiberg: 161 S.; Freiberg.

http://earth.google.com/download-earth.html/ : Nachterstedt City, in Google Earth. 2009.

Karpe, W. (1986a): Teilerkundung der Lagerstätte Nachterstedt, TF Schadeleben.unveröff. Bericht: 216 S.; BKW -Nachterstedt [MIBRAG-Archiv]

Karpe, W. (1986b): Die Beziehungen zwischen der Versalzung von Braunkohle und den prätertiären Strukturen im Raum Nachterstedt, Subherzyne Senke. Z. angew. Geol. 32 (3): 70-73; Berlin.

Karpe, W. (1975): Geologische Karte des Ascherslebener Sattels (Maßstab 1 : 50. 000). unveröffentlichte Karte, Manuskript; Halle [Archiv GLA LSA]

Knochenhauer, G. (1950) : Das Braunkohlenvorkommen von Nachterstedt in seiner geologischen Lage nach den neusten Aufschlüssen.unveröff. Meldearbeit Bergakademie Freiberg: 86. S., Freiberg

Lehman, R. (1933): Die Braunkohlenlagerstätte von Nachterstedt.In: Franke, P. [Hrsg.]:

Petley, D. 2009. Intriguing landslide at Nachterstedt in Germany, in Dave's landslide block: http://daveslandslideblog.blogspot.com/

Seichter, A. (1958): Feinstratigraphische Untersuchungen mittels Sporen- und Pollenanalysen an Braunkohlen aus Nachterstedt und Königsaue unter Berücksichtigung der Anwendungsmöglichkeiten von Remissionsmessungen.unveröff. Diss. BA Freiberg: 108 S.; Freiberg.

Voigt, E. (1963): Über Randtröge vor Schollenrändern und ihre Bedeutung im Gebiet der Mitteleuropäischen Senke und angrenzender Gebiete.Z. dt. geol. Ges., 114 (1962): 378-418, Hannover von der HOCHT, F. (1992) : Bestimmung der Evertebraten aus dem Unteroligozän von Nachterstedt. unveröff. Bericht: 4 S.; Kerpen-Balkhausen [Archiv GLA LSA]

Waltemate, G. (1956): Feinstratigraphische Untersuchungen der Braunkohle in den Tagebauen Nachterstedt und Königsaue.unveröff. Diplomarbeit. MLU Halle: 84 S.; Halle

Woldstedt, P. (1926): Zur Tektonik des subherzynen Beckens.Z. dt. geol. Ges., 76: 183 - 201; Berlin. 